\title{
Comparative studies on cellular resistance of bivalves from marine and brackish waters ${ }^{1}$
}

\author{
Hans Theede and Julius LAssig \\ Institut für Meereskunde der Universität Kiel, Kiel, Germany, \\ and \\ Institute of Marine Research, Helsinki/Helsingfors, Finland
}

KURZFASSUNG: Vergleichende Untersuchungen über zelluläre Resistenz bei Muscheln aus Meer- und Brackwasser. An vier euryhalinen poikilosmotischen Muschelarten aus Büsum (Nordseeküste, $\sim 30 \%$ S), der Kieler Förde (Beltsee, $\sim 15 \%$ S) und Trärminne (Finnischer Meerbusen, $\sim 6 \%$ S), wurden zur gleichen Jahreszeit (Herbst) vergleichende Untersuchungen über die zellulären Resistenzgrenzen durchgeführt. Auf Grund ihrer zellulären Salzgehaltsbereiche sind Macoma baltica und Mytilus edulis euryhaliner als Mya arenaria und Cardium edule. Die zelluläre Hitzeresistenz nimmt bei den Individuen aus der Nordsee in der Reihenfolge: Cardium, Mya, Macoma, Mytilus ab. Bei Exemplaren aus Trärminne ist die zelluläre Hitzeresistenz von Macoma am größten. Die zelluläre Gefrierresistenz ist unter den Muscheln aus der Nordsee am größten, fehlt dagegen praktisch bei den Tieren aus dem Finnischen Meerbusen. Bei verringertem Salzgehalt des Fundortwassers ist die zelluläre Resistenz der untersuchten Muscheln gegenüber Verdünnung des Außenmediums jeweils etwas erhöht, gleichzeitig nimmt die zelluläre Resistenz gegenüber anderen Außenfaktoren wie Hitze, Frost und hohen Salzkonzentrationen „unspezifisch“ ab.

\section{INTRODUCTION}

The few species of marine bivalves which can penetrate into highly diluted brackish water, e.g. the inner part of the Baltic Sea, are characterized by high tolerances not merely to low salinities but also to marked changes in the intensity of this and other environmental factors, such as temperature and oxygetr.

These species cannot compensate for environmental stresses by means of regulation. Environmental changes therefore tend to affect their organs, tissues and cells. The euryplastic adaptability of these body parts is the prerequisite for the high degree of resistance to strongly fluctuating environmental factors. The population dynamics in different biotopes will be better understood if the cellular mechanisms responsible for survival are analysed.

For a number of marine bivalve species, Schl一eper and his school (Schlieper \& Kowalski 1956, Schlieper 1958, 1966, Schlieper et al. 1960, 1967, Reshöft 1961,

1 Dedicated to Professor Dr. Friedrich Krüger on his 65th birthday, August 18, 1967. 
THEEDE 1965) and Vernberg et al. (1963) have demonstrated close relations between distribution and cellular resistance limits. In this respect it is interesting to note that experimentally obtained resistance limits may show seasonal fluctuations (e. g. DREGOLSKAYA 1963) and that the limits may be affected by adaptations, environmental factors and experimental conditions in many different ways (for references see PROSSER 1955, SChlieper and his school 1956-1967 as cited above, Kinne 1963, 1964a, 1964b, 1966, Precht 1964, Precht \& Christophersen 1965, Precht \& Lindner 1966).

The present study concerns four bivalve species which inhabit the North Sea with its almost oceanic salinity, as well as low salinity areas. LAssig (1965), in his compilation of the distribution limits of the marine bivalves of the northern Baltic area, gives the lower salinity limits for the species used in our experiments as follows: Macoma baltica 2 to $3 \%$ S, Mytilus edulis 4 to $4,5 \%$ S, Cardium lamarcki 4 to $4,5 \%$ S (see also Eisma 1965), Mya arenaria 4,5 to $5 \% \mathrm{~S}$.

\section{MATERIAL}

We used adult specimens of Mytilus edulis L., Cardium edule L. (as for Cardium from Tyärminne, see below), Macoma baltica (L.) and Mya arenaria L. from three localities with distinctly different salinities (to which the animals were thus maximally adapted). The localities were Büsum (ca. $30 \% \mathrm{~S}$ ) on the North Sea coast, Kieler Förde (ca. $15 \%$ S) in the Belt Sea, and Tvärminne (ca. $6 \% \mathrm{~S}$ ) at the entrance of the Gulf of Finland.

Petersen (1958), in his paper on the species of Cardium living in Danish brackish waters, holds $C$. edule to be a marine species which does not occur in waters with a salinity below 20 to $25 \%$, while C. lamarcki ReEve is confined to brackish waters with a salinity from ca. $25 \%$ to ca. $5 \%$. Kolr $(1959,1961)$, using the characteristics given by Petersen, stated that the species living in Finnish waters is C. lamarcki. According to the salinity ranges given by PETERsen the Cardium species of the Kieler Förde should also be C. lamarcki. However, we could not find marked morphological differences between C. edule from the North Sea and Cardium from the Kieler Förde where the population obviously belonged to $C$. edule. A number of these specimens were sent to Dr. D. Exsma, Den Helder. Dr. Ersma agreed with our point of view.

At Büsum, Cardium, Macoma and Mya were dug out from the thud flat at low tide, while Mytilus were collected from a mole. In Kiel, Mya were dug out in shallow water at Laboe, Cardium were collected at the same locality, Macoma were taken at buoy "B" in ca. $10 \mathrm{~m}$ depth. Mytilus were scraped off from pile-work in the harbour. The material from Tvärminne was dredged in 4 to $5 \mathrm{~m}$ depth in the vicinity of the Zoological Station: Cardium, Macoma and $M y a$ at localities with a bottom consisting of sand and mud, Mytilus from vegetation of Fucus vesiculosus where the bivalve is found attached abundantly to this brown alga. The distribution of these lamellibranchs in the inner Baltic Sea has been described by LAssig (1965).

Until the beginning of each experiment the test individuals were kept in aerated glass aquaria at a constant temperature of $10^{\circ} \mathrm{C}$, and at salinities corresponding to 
those at the localities from which they were collected. The storage time varied from three days to three weels.

\section{METHODS}

Our experiments were carried out with living isolated pieces of tissue taken from the fringes of the gills. The areas of these pieces varied from 4 to $20 \mathrm{~mm}^{2}$ according to the species. As main criterion for the degree of injury caused by the different extreme conditions we used the activity of the terminal cilia. The activity of these cilia was classified according to an estimated scale ranging from 3 to $0 ; 3$ stands for normal ciliary activity, 2 for slightly reduced, 1.5 for half-reduced, 1 for more than halfreduced, 0.5 for very strongly reduced, and 0 for ceased activity. For every resistance experiment we used 5 to 10 gill pieces taken from different specimens of the same species.

The experiments were performed in October of 1965 and 1966, respectively, in order to exclude possible seasonal variations in resistance. The results obtained in both years were so similar that we decided to present the data together, i. e. without reference to the year they were obtained.

\section{Cellular freezing resistance}

For these experiments we used a method described by THeene (1965). The test temperature was $-10^{\circ} \mathrm{C}\left( \pm 0.3^{\circ}\right)$. During the freezing experiments the gill pieces (in $0.5 \mathrm{ml}$ sea-water of appropriate salinity) were enclosed in thin-walled polyethylene chambers $(\phi 4 \mathrm{~cm}$, height $7 \mathrm{~cm})$ which were immersed into the cooling liquid of a Colora apparatus. After 15 to 20 seconds the water in the chambers was frozen. At suitable time intervals the chambers, one by one, were removed from the cooling liquid and their contents quickly (within 15 to $20 \mathrm{sec}$.) thawed in sea-water of normal room temperature and appropriate salinity. After a few minutes of recovery the degree of injury to the tissues was microscopically determined in terms of ciliary activity.

\section{Cellular heat resistance}

The observations on the heat resistance of isolated gill tissues were performed at a constant lethal temperature of $36^{\circ} \mathrm{C}$. The apparatus used for this purpose is described by Schlieper, Fuügel \& THEede (1967). A small double-walled plastic chamber was set up on the stage of a microscope. Warm water of constant temperature circulated through a water tank and the outer chamber, keeping the inner chamber containing sea-water and gill pieces at the constant test temperature. The temperature of the water in the tank was regulated with the aid of an immersion heater (Thermomix, B. Braun, Melsungen) supplied with a contact thermometer and relay control. The temperature in the inner chamber was continuously controlled with a calibrated 
mercury thermometer. The water of the inner chamber was kept in rotation with a magnetic stirrer since, during preliminary experiments, ciliary activity was sustained significantly longer in a stirred than in a stagnant medium. The permanent mixing of the medium favours a uniform distribution and constancy of the temperature as well as a sufficient oxygen supply.

The salinity of the test water corresponded always to the salinity of the habitat from which the bivalves had been collected.

At appropriate time intervals survival of gill pieces was estimated from activity rates of the terminal cilia.

\section{Cellular salinity resistance}

Experiments on cellular salinity resistance were conducted using isolated gill tissue exposed to a series of progressively increasing salinities ranging from 0 to $70 \%$ S. Salinities below $15 \%$ were obtained by diluting Baltic Sea water from Kiel with a mixture of 2 parts distilled water and 1 part Kiel tap water. Higher salinities were obtained by adding artificial sea-salt to Kiel brackish water. 25 to $30 \mathrm{ml}$ of each kind of test water were pipetted into petri dishes $(\phi 10 \mathrm{~cm}) .4$ pieces of gill tissue from different specimens were transferred into each dish. The dishes were kept at $10^{\circ} \mathrm{C}$ for 24 hours whereupon the activity of the terminal cilia was estimated.

\section{RESULTS}

\section{Cellular freezing resistance}

According to KanwiSher (1955, 1966), Theede (1965), Meryman (1966), and Sömme (1966), a number of marine mollusc species possess a considerable resistance to freezing. Our experiments are closely related to those performed by THEede (1965). Compared with employing intact whole animals the present method has the advantage that only a small water volume is needed, and consequently, temperature decrease and freezing occurs more rapidly.

In order to be able to present very different low and high resistance values in a single diagram, the results were plotted in a semi-logarithmic coordinate system. Approximate straight lines were obtained if, after freezing and thawing, the average ciliary activity of the tissue pieces was plotted at normal room temperature. These lines reflect the degree of injury as a function of the time of exposure to cold. As expected, the degree of injury to the tissue increases with prolonged exposure to the test temperature (Fig. 1). In the individuals from the North Sea, cellular freezing resistance is greatest in Mytilus and somewhat lower in Cardium, Mya and Macoma. Pieces of gill tissue from Mytilus still show distinct ciliary beats after one hour exposure to $-10^{\circ} \mathrm{C}$. In Mytilus from the Kieler Förde the survival capacity is reduced to about $10 \%$ compared to the animals from the North Sea. In the other species from the Kieler Förde the reduction of the cellular resistance is similar. 
THEEDE (1965) already found that the cellular freezing resistance in different lamellibranchs - amongst these Mytilus edulis, Cardium edule, Macoma baltica and Mya arenaria - was obviously lower in individuals from the Kieler Förde than in those from the North Sea. According to the present study this tendency is even more pronounced in specimens from still lower salinities, as shown by the experiments on material from Tvärminne, where the species live near their extreme limits of distribution. At the experimental temperature the activity of the gill tissue of these animals

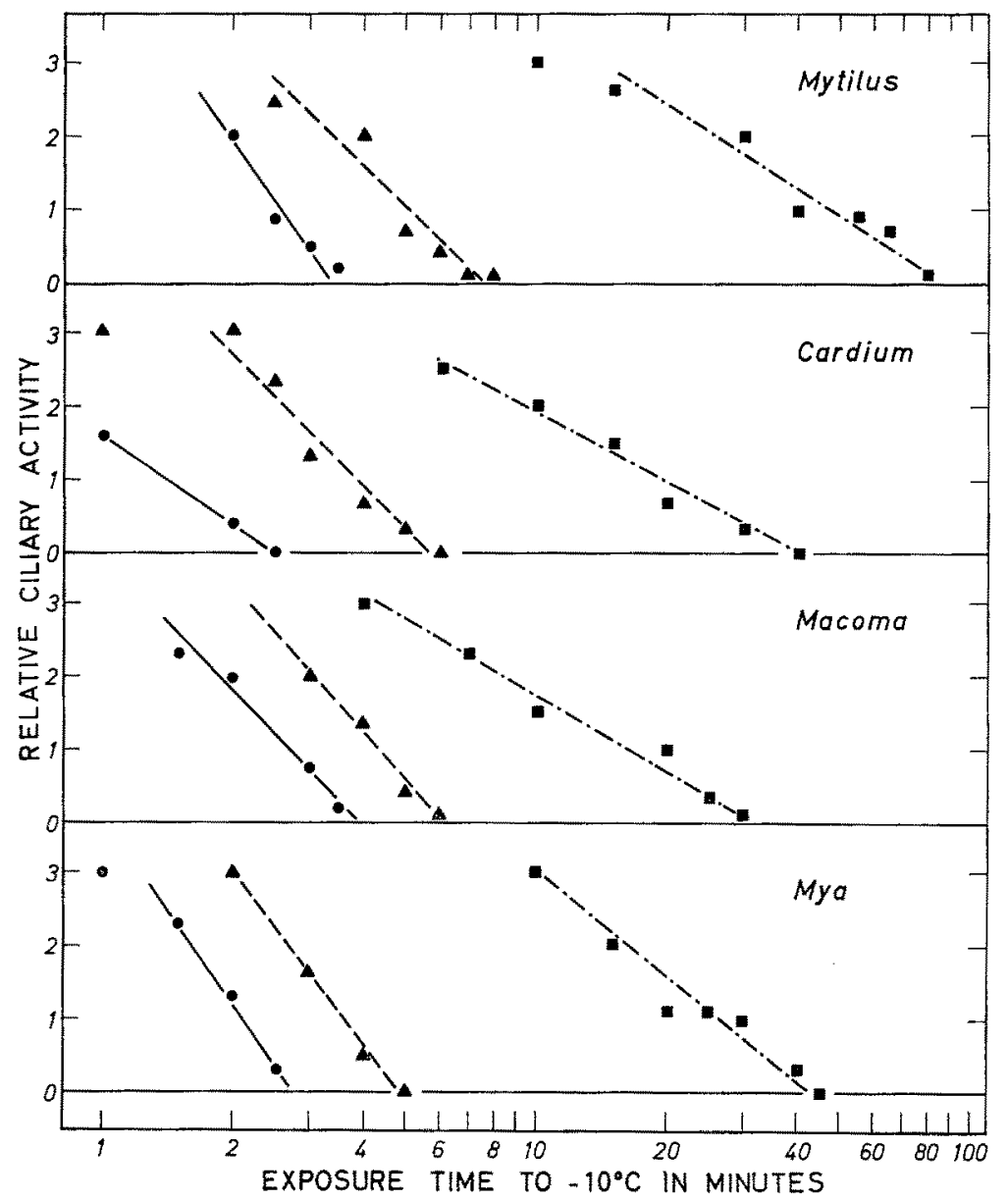

Fig. 1: Cellular freezing resistance of Mytilus edulis, Cardium edule (in Tvärminne C. lamarcki), Macoma baltica and Mya arenaria from three localities: Büsum (North Sea,

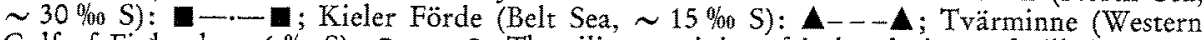
Gulf of Finland, $\sim 6 \% \mathrm{~S}$ ): $-\longrightarrow$. The ciliary activity of isolated pieces of gill tissue was observed at room temperature after freezing at $-10^{\circ} \mathrm{C}$ and subsequent thawing. The activity of the cilia was estimated and classified as follows: $3=$ normal activity; $1.5=$ activity reduced to half of normal; $0.5=$ strongly reduced activity; $0=$ no activity. Every dot is an average of 8 to 10 single observations 
broke down so rapidly that one can hardly speak of any cellular freezing resistance at all. Here the exposure to $-10^{\circ} \mathrm{C}$ killed the tissue within 2 to 3 minutes.

\section{Cellular heat resistance}

Salinity has been shown to affect the heat resistance of marine and brackish water Protozoa and other invertebrates as well as that of isolated tissues and cells (Schlieper 1958, Kinne 1964a, b, Precht \& Lindner 1966, Vogel 1966).

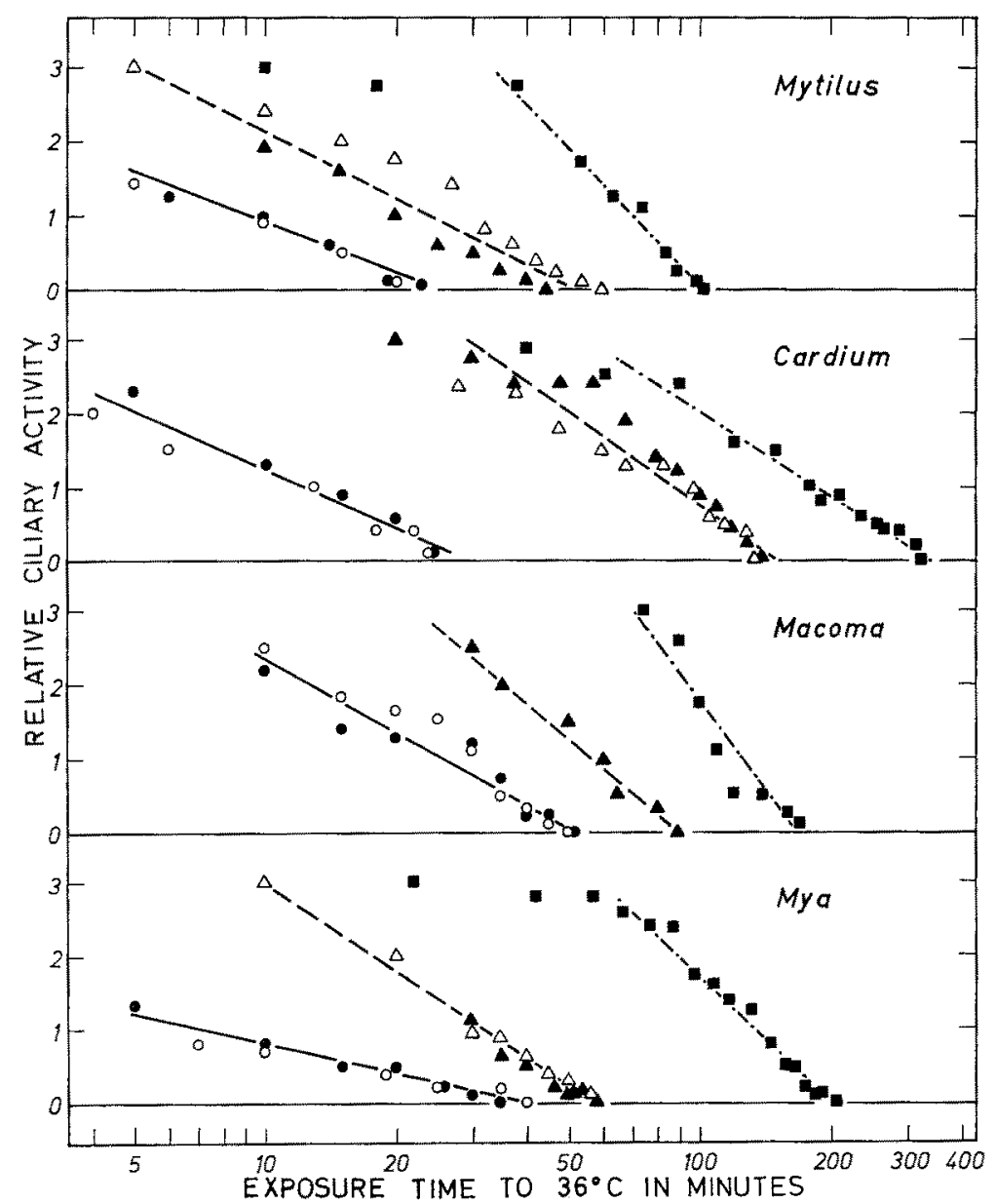

Fig. 2: Cellular heat resistance of bivalves from Büsum (North Sea, $\sim 30 \% 0$ ): -D-Dieler Förde (Belt Sea, $\sim 15 \% \mathrm{~S}$ ): $\mathbf{\Delta}---\boldsymbol{\Delta}$ and $\triangle---\Delta$ (two separate series of experiments; Trärminne (Western Gulf of Finland, $\sim 6 \% \mathrm{~S}$ ): $-\longrightarrow$ and $\mathrm{O}-\mathrm{O}$ (two separate series of experiments). The decrease of the ciliary activity at $+36^{\circ} \mathrm{C}$ was continuously observed. Every dot is an average of 5 single observations on pieces of gill tissue from different specimens. The scale of classification is the same as in Figure 1 
The average times of survival obtained for isolated tissue pieces at $36^{\circ} \mathrm{C}$ (Table 1) give a measure of the duration of survival, not of the condition of the surviving tissue. The degree of injury may be assessed by observing relative ciliary activity of the same tissue pieces in relation to the duration of their exposure to heat (Fig. 2). From these data we get the following information on the thermal resistance of the tissues studied.

Table 1

Average survival time in minutes at $36^{\circ} \mathrm{C}$, indicating differences in heat resistances of isolated gill tissue of four species of lamellibranchs from marine and brackish water localities. Prior to the experiments the test individuals were kept at a constant temperature of $10^{\circ} \mathrm{C}$. (In brackets: Standard deviations.) "C. lamarcki

\begin{tabular}{|lccc|}
\hline Species/Locality & $\begin{array}{c}\text { Büsum, } \\
\text { North Sea } \\
\text { ca. 30\% S }\end{array}$ & $\begin{array}{c}\text { Kiel, } \\
\text { Baltic Sea } \\
\text { ca.15\%0 S }\end{array}$ & $\begin{array}{c}\text { Trärminne, } \\
\text { Baltic Sea } \\
\text { ca.6\% }\end{array}$ \\
\hline Mytilus edulis & $82( \pm 9)$ & $37( \pm 11)$ & $21( \pm 4)$ \\
Cardium edule & $257( \pm 20)$ & $130( \pm 11)$ & $24 \%( \pm 3)$ \\
Macoma baltica & $166( \pm 9)$ & $74( \pm 8)$ & $42( \pm 7)$ \\
Mya arenaria & $178( \pm 14)$ & $50( \pm 9)$ & $26( \pm 3)$ \\
\hline
\end{tabular}

In the North Sea, cellular heat resistance of Cardium edule is higher than that of Mya arenaria and Macoma baltica, while that of Mytilus edulis is the lowest one. At a reduced salinity the thermal resistance in each species is lowered. This is clearly seen in individuals from the Kieler Förde, and even more so in those from the highly diluted waters near Tvärminne, where the cellular resistance of the lamellibranchs has decreased considerably. Amongst the animals from. Tvärminne the relatively highest resistance was found in Macoma baltica. Accordingly, with decreasing habitat salinity, the decrease of heat resistance is related also to the degree of euryhalinity. The results obtained agree well with those presented by SCHLIEPER \& KOwALSKI (1956) and RESHÖFT (1961) for Mytilus edulis from the North Sea and from the Kieler Förde.

\section{Cellular salinity resistance}

Only a few studies on cellular salinity limits of marine invertebrates have been made (Pilgrm 1953, Schlieper et al. 1960, Reshöft 1961, Vernberg et al. 1963, TheEde 1965, Schlieper et al. 1967). In poikilosmotic species the close relation to the resistance of intact whole animals, is easily seen.

All four species tested in this study are euryhaline. In the North Sea, during low tides, they may have to tolerate considerable dilutions as well as unusually high salinities. Hence, they must have a wide range of physiological salinity resistance. In the Baltic Sea, where the tidal phenomenon has practically no ecological significance, the bivalyes still have to endure considerable salinity fluctuations (e. g. SEGERSTRR̊LE 1951, 1957; KäNDLER 1959), due to varying hydrographical conditions.

The results of our experiments are shown in Figure 3. The resistance of the tissue to high salinity is strongest in Mytilus and Macoma from the North Sea; it is some- 
what lower in Mya and Cardium. In regard to the degree of resistance to dilution, there is no marked difference between the values obtained for Mytilus, Macoma or Mya from the North Sea, however Cardium shows a clearly lower resistance.

The tolerance range is highest in specimens from the North Sea, and gradually gets narrower in habitats of lower salinity. At the same time the tolerance range shifts towards lower salinity. Comparing the size of the changes of the salinity resistance in

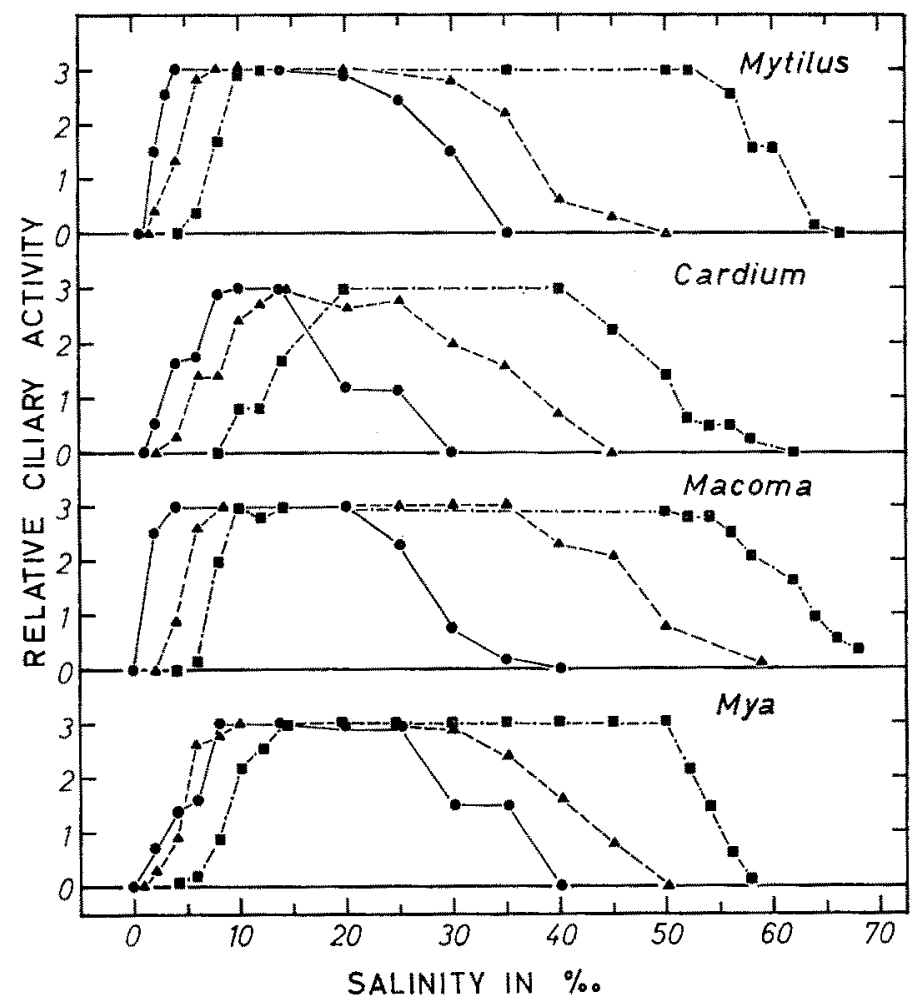

Fig. 3: Cellularsalinity resistance of bivalves from Büsum (North Sea, $\sim 30 \%$ S):

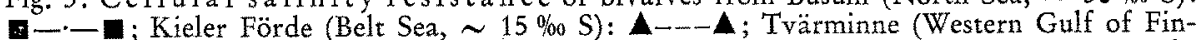
land, $\sim 6 \%$ S): - Experimental temperature: $+10^{\circ} \mathrm{C}$. The ciliary activity was observed 24 hours after the transfer of gill tissue pieces into a series of containers with water of appropriate salinities. The dots are averages of 8 to 10 single observations. The scale of classification is the same as in Figure 1

specimens from marine habitats and from brackish water, we find that the changes in lower salinity limits are obviously smaller than those in upper limits of salinity resistance. However, one should keep in mind that small salinity changes at the lower end of the scale tend to have more pronounced physiological consequences. While in Mytilus from the North Sea and the coast of Finland there is a difference of about $30 \% \mathrm{~S}$ between the upper resistance limits, the difference at the lower end of the salinity range is only about 5 to $6 \% \mathrm{~S}$. This tendency is obvious in all species tested and probably represents a general phenomenon. At least in Mytilus - as shown by Theede (1965) 


\section{Studies on cellular resistance of bivalves}

for specimens from the North Sea and from Kiel - such a difference in the range of the cellular salinity resistance is a consequence of non-genetic long-term cellular salinity adaptation. A comparable measure of the euryhalinity is obtained only if the total cellular resistance range of the populations is considered. According to these values Macoma and Mytilus are evidently more euryhaline than Mya and Cardium.

\section{DISCUSSION}

The ecological conditions of a certain locality may often modify the tolerances and functional abilities of the animal population living there to such an extent, that single observations on one population cannot be generalized or assumed to be valid for the whole distribution area of the species concerned. By measuring the physiological tolerances of individuals from widely differing localities one may get data on the reaction range within which all the resistance limits of one species can be modified.

The present study on four euryhaline bivalve species, which penetrate far into brackish water, shows that decreasing habitat salinities increase to some extent the tolerance to low salinities, but that at the same time the tolerance to other extreme factors e. g. heat, freezing and high salinities decreases strongly. THEEDE (1965) suggested that this phenomenon indicates a general unspecific decrease of cellular tolerance in poikilosmotic species, and that adaptation to lowered salinities causes a decrease of the intermolecular forces in the macromolecular region, responsible for the structural stability of the protoplasm. These processes are partly reversible. Large changes in cellular resistance to freezing and salinity could be obtained in adult individuals in adaptation experiments lasting a few weeks (THEEDE 1965). It seems probable that the unspecific decrease of cellular resistance observed in brackish water is connected with a decreased tolerance of important enzymes. Further studies on these problems are being planned.

The changes in tolerance are also interesting from the ecological point of view. Thus, for instance, the bivalves from the Gulf of Finland living at salinities around $6 \%$ have almost completely lost their ability to survive freezing (measured at $-10^{\circ} \mathrm{C}$ ), an ability possessed by populations living in fully marine waters. These bivalves are able to survive partial freezing of shorter duration on the dry mud flats of the North Sea during low tide. Mass mortality was observed only during very cold winters (CRISP 1964, ZIEGELMEIER 1964). In the inner Baltic these species will survive the cold only if the individuals remain covered by water, which at these salinities freezes just below zero. Individuals which, in summer, have chosen localities too close to the shore or the water line on rocks and piles will die at first low tide coincident with temperatures below freezing. The ability to tolerate long exposure to low water temperatures above the freezing point (chilling-resistance) does not seem to be decreased.

\section{SUMMARY}

1. The cellular resistance of representatives from four euryhaline poikilosmotic bivalves caught in Büsum (North Sea, $\sim 30 \%$ S), Kieler Förde (Belt Sea, 
$\sim 15 \%$ S), and Tvärminne (Gulf of Finland, $\sim 6 \%$ S) has been tested. All experiments were performed in October.

2. According to their cellular salinity ranges Macoma baltica and Mytilus edulis are more euryhaline than Mya arenaria and Cardium edule.

3. The cellular heat resistance decreases in specimens from the North Sea in the following order: Cardium, Mya, Macoma, Mytilus. Among the representatives collected near Tvärminne, Macoma has the highest heat resistance.

4. The cellular freezing resistance in specimens from the North Sea is highest in Mytilus. The bivalves of the Gulf of Finland practically lack resistance to freezing.

5. In localities of decreased salinity the cellular resistance of these bivalves to a dilution of the external medium is somewhat increased, but simultaneously the cellular resistance to other environmental factors, such as heat, freezing and high salinity, decreases unspecifically.

Acknowledgements: The authors wish to express their gratitude to Dr. K. J. Purasjoki of the Tvärminne Zoological Station for sending living animals from Finland. Part of the experiments were performed with an apparatus placed at the disposal of Prof. C. Schlieper by the "Deutsche Forschungsgemeinschaft".

\section{LITERATURE CITED}

CrIsp, D. J., 1964. The effects of the winter of $1962 / 63$ on the British marine fauna. Helgoländer wiss. Meeresunters. 10, 313-327.

Dregolskaya, I. N., 1963. Heat resistance of ciliated epithelium of Mytilus galloprovincialis L. from the Black sea. In: Problems of cytoecology of animals. [Russ.] Akad. Nauk SSSR, Moskva. (Coll. Art. Inst. Cytoecol. 6, 43-50.)

Ersma, D., 1965. Shell-characteristics of Cardium edule L. as indicators of salinity. Neth. J. Sea Res. 2, 493-540.

KäNDLER, R., 1959. Hydrographische Beobachtungen in der Kieler Förde 1952-57. Kieler Meeresforsch. 15, 145-156.

KANWISHER, J. W., 1955. Freezing in intertidal animals. Biol. Bull. mar. biol. Lab., Woods Hole 109, 56-63.

- 1966. Freezing in intertidal animals. In: Cryobiology. Ed. by H. T. Meryman. Acad. Pr., New York, 487-494.

KinNe, O., 1963. The effects of temperature and salinity on marine and brackish water animals. 1. Temperature. Oceanogr. mar. Biol. Ann. Rev. 1, 301-340.

- 1964a. The effects of temperature and salinity on marine and brackish water animals. 2. Salinity and temperature-salinity combinations. Oceanogr. mar. Biol. Ann. Rev. 2, 281-339.

- 1964b. Non-genetic adaptation to temperature and salinity. Helgoländer wiss. Meeresunters. 9, $433-458$.

- 1966. Physiological aspects of animal life in estuaries with special reference to salinity. Neth. J. Sea Res. 3, 222-244.

KoLI, L., 1959. Sydänsimpukkamme lajikysymys. Luonnon Tutk. 63, 91-92.

- 1961. Die Molluskenfauna des Brackwassergebietes bei Tvärminne, Südwestfinnland. Annls zool. Soc. zool.-bot. fenn. Vanamo 22, 1-22.

LAssig, J., 1965: The distribution of marine and brackish water lamellibranchs in the northern Baltic area. Commentat. biol. 28 (5), 1-41.

Meryman, H. T., 1966. Review of biological freezing. In: Cryobiology. Ed. by H. T. Meryman. Acad. Pr., New York, 1-114. 
Petersen, Hørner G., 1958. Notes on the growth and biology of the different Cardium species in Danish brackish water areas. Meddr Danm. Fisk. -og Havunders. (N.S.) 2 (22), 1-31.

PIlgRIM, R. L. C., 1953. Osmotic relations in molluscan contractile tissues. 2. Isolated gill preparations from lamellibranchs (Mytilus edulis L., Ostrea edulis L., Anodonta cygnea L.) J. exp. Biol. 30, 318-330.

Precht, H., 1964. Uber die Resistenzadaptation wechselwarmer Tiere an extreme Temperaturen und ihre Ursachen. Helgoländer wiss. Meeresunters. 9, 392-411.

- \& Christophersen, J., 1965. Temperaturadaptation des Cilienepithels isolierter Kiemen und Fühlerspitzen von Mollusken. Z. weiss. Zool. 171, 197-209.

- \& LindneR, E., 1966. Reaktionen, Regulationen und Adaptationen der Tiere nach Veränderung von Temperatur und Salzgehalt. Versuche mit Zootbamnium biketes (Ciliata, Peritricha). Helgoländer wiss. Meeresunters. 13, 354-368.

Prosser, C. L., 1955. Physiological variation in animals. Biol. Rev. 30, 229-262.

REsHöFT, K., 1961. Untersuchungen zur zellulären osmotischen und thermischen Resistenz verschiedener Lamellibranchier der deutschen Küstengewässer. Kieler Meeresforsch. 17, 65-84.

Schlifper, C., 1958. Physiologie des Brackwassers. In: Remane, A. \& C. Schlieper: Die Biologie des Brackwassers. Schweizerbart, Stuttgart. (Binnengereässer 22, 217-330.)

- 1966. Genetic and non-genetic cellular resistance adaptation in marine invertebrates. $\mathrm{Hel}$ goländer wiss. Meeresunters. 14, 482-502.

- Fuügex, H. \& Rudolf, J., 1960. Temperature and salinity relationships in marine bottom invertebrates. Experientia 16, 470-477.

- - \& Theede H., 1967. Comparative investigations on ecological cell physiology of marine temperate and tropical bottom invertebrates. Physiol Zool. (in press).

- \& Kowatskr, R., 1956. Uber den Einfluß des Mediums auf die thermische und osmotische Resistenz des Kiemengewebes der Miesmuschel Mytilus edulis L. Kieler Meeresforsch. 12, $37-45$

SEGERSTRÅLE, S. G., 1951. The seasonal fluctuations in the salinity off the coast of Finland and their biological significance. Commentat. biol. 13 (3), 1-27.

- 1957. Baltic sea. In: Treatise on marine ecology and paleoecology. Vol. 1. Ecology. Ed. by J. W. Hedgpeth. (Mem. geol. Soc. Am. 67, 751-800.)

Sömme, L., 1966. Seasonal changes in the freezing-tolerance of some intertidal animals. Nytt Mag. Zool. 13, 52-55.

THEEDE, H., 1965. Vergleichende experimentelle Untersuchungen über die zelluläre Gefrierresistenz mariner Muscheln. Kieler Meeresforsch. 21, 153-166.

Vernberg, F. J., Schlieper, C. \& Schneider, D. E., 1963. The influence of temperature and salinity on ciliary activity of excised gill tissue of molluscs from North Carolina. Comp. Biochem. Physiol. 8, 271-285.

Vogel, W., 1966. Ober die Hitze- und Kälteresistenz von Zoothamnium biketes PReCHT (Ciliata, Peritr.). Z. wiss. Zool. 173, 344-378.

Ziegelmeier, E., 1964. Einwirkungen des kalten Winters 1962/63 auf das Makrobenthos im Ostteil der Deutschen Bucht. Helgoländer wiss. Meeresunters. 10, 276-282. 